\title{
ONTLENING VAN NEDERLANDSE SAMENSTELLINGEN IN HET SURINAAMS ${ }^{1}$ ) \\ DOOR
}

\section{R. D. Simons en J. Voorhoeve}

Omstreeks 1850 begint het Nederlandse element in de Negerengelse woordenschat duidelijker naar voren te komen.. In 1800 kwamen er nog maar zeer weinig Nederlandse leenwoorden in deze taal voor ${ }^{2}$ ). Wanneer men de bijbelvertaling van 1829 (waarin al belangrijk meer woorden van Nederlandse herkomst voorkomen dan in de vertalingen van C. L. SchUMANN uit ca 1780 ) vergelijkt met de volgende drukken, valt dadelijk de sterke toeneming van Nederlandse leenwoorden op. Vele Engelse leenwoorden worden vervangen door Nederlandse: kwarri (quarrel) > feti, tegedere (together) > makandra, etc.

Aan het einde van dit artikel publiceren wij een verzameling Surinaamse woorden, die een opvallende gelijkenis vertonen met een aequivalente $\mathrm{Ne}$ derlandse samenstelling. Wij rangschikten dit materiaal in drie groepen:

I woorden, waarvan beide samenstellende delen in het Surinaams zinvol

zijn (d.w.z. ook buiten de samenstelling een eigen betekenis hebben);

II woorden, waarvan slechts één der samenstellende delen zinvol is in het Surinaams;

III woorden, waarin men geen zinvol deel kan ontdekken.

Wij spreken hier met opzet niet van Surinaamse samenstellingen. Voor het Surinaamse taalgevoel vormen de delen van foroisi (voorhuis) één geheel. Men kan hen slechts afzonderlijk zien door vergelijking met het Nederlandse aequivalent ,,voorhuis”. Dat dit in het Nederlands een samenstelling is, garandeert natuurlijk niet, dat ook foroisi een samenstelling zal zijn. Theoretisch is het mogelijk, dat een dergelijk gecreoliseerd element -oisi zich via analoog gevormde woorden als kumakoisi (gemakhuis, WC) en peprewoisi (peperhuis, puntzak) tot een productief woorddeel ontwikkelt met eigen functie of betekenis. Dit is hier echter niet het geval. Wij kunnen geen nieuwe zinvolle samenstelling vormen met het element -oisi. Zoiets is wel mogelijk met het element -oso, getuige een zinvolle nieuwvorming als *pleenoso (hangar). ${ }^{3}$ )

1) Dit artikel berust op een verzameling van R. D. Simons. Een gesprek over de uit dit materiaal naar voren gekomen problemen voerde tot samenwerking met J. Voorhoeve. Dankbaar werd gebruik gemaakt van de op last van Prof. Dr W. Gs. Hellinga opgestelde aantekeningen op dit materiaal door Mevr. L. NiJŝ́ten-HöfTE. Deze aantekeningen bevinden zich op het Bureau Taalonderzoek Suriname.

Het materiaal zelf wordt aan het einde van dit artikel in systematische orde gepubliceerd.

2) Zie hierover hoofdstuk IX in L. L. E. Rens: The Historical and Social Background of Surinam's Negro-English. Amsterdam, 1953.

3) Zie voor dit principe J. VoorhoEve: Voorstudies tot een beschrijving van het Sranan Tongo, Negerengels van Suriname (A'dam, 1953), pp. 34 v. 
Wij willen in dit artikel slechts de principes aangeven, volgens welke een materiaal als het hieronder gepubliceerde, dient te worden onderzocht. Het is dus niet nodig voor elk geval afzonderlijk na te gaan, op de bovenomschreven wijze, of wij van een samenstelling mogen spreken of niet. In elk geval zal men in groep III van het materiaal geen samenstellingen aantreffen.

Kan men, bij de woorden uit groep I, spreken van vertaalde ontledingen? Een samenstelling als korkutreki (kurketrekker) is ongetwijfeld een ontlening. Het element treki (een aftreksel maken) past zo slecht bij zijn component korku (kurk) en staat op zo'n ongewone plaats in de samenstelling, dat wij ons afvragen of de Surinamer hier nog wel het losse element treki herkent. Een creolisering uit ,,kurketrekker” ligt hier voor de hand. De samenstelling freemusu (vleermuis) zou letterlijk vertaald moeten worden met ,,vliegmuts". Het beeld van de ,,vliegende muts" is zo ongewoon, dat wij liever aan een creolisering uit ,,vleermuis" denken.

Een woord als sraktioso (slachthuis) kan een vertaalde ontlening zijn uit het Nederlands. Dit is echter niet noodzakelijk. Het woord kan ook heel wel zelfstandig gevormd zijn uit de bestaande elementen srakti (slachten) en oso (huis). Het bestaan van een overeenkomstige Nederlandse samenstelling ,,slachthuis" kan louter toeval zijn. Het is dus allerminst uitgesloten, dat wij in groep I veelal te maken hebben met eigen Surinaamse vormingen. Een woord als kawfree (koeienvlieg, horzel) heeft geen Nederlands aequivalent en moet dus een zelfstandige vorming zijn. De gespecialiseerde betekenis van trowoso (bruiloft) doet ook aan een eigen vorming denken. Naast de waarschijnlijk eigen vorming fetikaka (kemphaan in figuurlijke betekenis: vechtersbaas) staat de duidelijke ontlening kempanki (kemphaan in letterlijke betekenis).

Alle woorden met betekenisloze elementen (groepen in en III) moeten ontleend zijn. De woorden uit groep ir plaatsen ons echter voor een nieuw probleem: is het zinvolle element vertaald of toevallig zinvol gecreoliseerd ? Een samenstelling als freemusu toonde ons immers, dat de creolisering als bij toeval zinvolle elementen kon opleveren. Dit is zelfs een zeer instructief voorbeeld, omdat hier een in het huidige Nederlands betekenisloos element ,,vleer" in zijn gecreoliseerde vorm free door een gelukkig toeval de betekenis ,,vliegen” kreeg. Wanneer wij FocKE ${ }^{1}$ ) mogen geloven, die namelijk spikrikati (spiegelkat, een vissoort) verklaart als ,,waarschijnlijk verbasterd uit spikkelkat" (een bewering, die vooralsnog onbewijsbaar is, al vonden wij deze naam inderdaad bij HARTSINCK), dan zou de oorspronkelijke Nederlandse benaming ,,spikkelkat” gecreoliseerd zijn tot spikrikati. De creolisering leverde bij toeval het zinvolle element spikri (spiegel) op. Terugvertaling in het Nederlands voerde tenslotte tot de Nederlandse benaming ,,spiegelkat".

Creolisering (en dus niet vertaling) van de Nederlandse samenstelling "peperhuis" zou aldus de vorm peprewoisi kunnen hebben opgeleverd, waarvan het eerste element pepre ten onrechte de indruk wekt door vertaling tot stand te zijn gekomen. Is dit eerste element nu vertaald of bij toeval zinvol gecreoliseerd? Een antwoord is hier niet te geven. Dit hoeft ook niet, want een vorm als bunkopu (goedkoop) leert ons, dat een gedeeltelijke vertaling mogelijk was.

1) H. C. Focke: Neger-Engelsch woordenboek (Leiden, 1855), p. 125. 
Terecht vraagt men zich bij de bestudering van een dergelijke vorm af, waarom men het tweede element onvertaald liet, terwijl toch een Surinaams aequivalent van , koop" voorhanden was. Sterker: waarom heeft men het element „,huis" in sommige Nederlandse samenstellingen onvertaald gelaten, terwijl andere samenstellingen aantonen (zie bijv. pantioso), dat men dit element zeer wel als lid van de samenstelling kon herkennen en dus vertalen.

Op deze vraag is geen algemeen antwoord te geven. Er zijn drie verschillende verklaringen mogelijk: een structurele, een lexicologische en een historische verklaring. Wij zullen deze verklaringsmogelijkheden steeds aan de hand van een enkel voorbeeld demonstreren.

1 De structurele verklaring

Men moet de bekendheid met de Nederlandse taalstructuur in Suriname niet overschatten, vooral niet in vroeger tijden en dan bij de spraakmakende gemeente. Het zou mogelijk kunnen zijn, dat de oorspronkelijke Nederlandse samenstelling niet in zijn structuur werd doorzien. Hierdoor kon men de afzonderlijke delen van de samenstelling niet onderscheiden. Het woord kurketrekker is op een voor Suriname vreemde wijze samengesteld. Men kent in Suriname geen van werkwoorden afgeleide nomina, die niet op personen slaan. Daarom bracht men het woord ,,trekker” niet licht in verband met het verbum ,,trekken”. En al had men dit verband gelegd, dan nog had het voorkomen van een zgn. verbum als tweede lid van de samenstelling de Surinamer in verwarring moeten brengen. Hij had iets verwacht als ,,trekkurk" (*harikorku).

2 De lexicologische verklaring

De Surinaamse woorden zijn dikwijls maar ten dele aequivalent met de Nederlandse. Het Surinaamse woord kan in een ander begripsveld liggen. Zo heeft oso de betekenis van ,woonruimte, zowel voor mens als dier". Men spreekt van oso bij een menselijk woonhuis, maar ook bij een wespennest of de schaal van een schildpad. Het element ,huis" in de Nederlandse samenstelling ,,peperhuis" kon daarom moeilijk in verband gebracht worden met het Surinaamse woord oso. De Surinamers ontdekten dus het element ,,huis" niet als afzonderlijk betekenisdragend deel van de samenstelling en vertaalden het niet. De creolisering kumakoisi schijnt niet op dezelfde wijze verklaard te kunnen worden. Allereerst denkt men bij het apart staande ,huisje” op het erf eerder aan een woonhuis, bovendien vinden wij bij Focke ${ }^{1}$ ) het woord pikinoso (gemakhuis, secreet). Dit zal echter de vertaling geweest zijn van het Nederlandse ",huisje”, waarin het element ,huis"' veel gemakkelijker te herkennen was dan in ,,gemakhuis". En dan ziet men bovendien, dat het element oso in deze samenstelling zo zwak stond, dat zij kon verbasteren tot pikjonso (FOCKE geeft deze uitspraak tussen haken).

\section{De historische verklaring}

Een woord als kempanki (kemphaan) zou misschien ook lexicologisch verklaard kunnen worden. In dat geval zou de betekenis van kaka (haan) zo gebonden zijn aan één vogelsoort, dat overdracht op een andere soort niet goed mogelijk was. Het zou echter ook kunnen zijn, dat ten tijde van de ontlening het Nederlandse woord ,haan" onvoldoende bekend was in Suriname en daarom niet in verband werd gebracht met het Surinaamse

1) H. C. FockE: Neger-Engelsch woordenboek (Leiden, 1855), p. 47. 
woord kaka. Wij mogen er niet zonder meer van uitgaan, dat Nederlandse woorden als ,,haan”, ,, brood”, ,,koop”, ,,zuur”, etc. algemeen bekend waren onder de Surinamers van vroeger. Een dergelijke verklaring hanteren wij echter ongaarne. Wij kennen de oudere taalfasen van het Surinaams praktisch niet en kunnen dus de ouderdom van een dergelijke ontlening niet vaststellen. Bovendien weten wij niets van de kennis van het Nederlands in vroeger tijd.

Uit de woordenboeken van Focke en WULLSCHLÄGEL kennen wij de nu verouderde samenstelling smokosipi (rookschip). Men bezat dus vroeger voor dit begrip een zinvolle samenstelling in het Surinaams. Toch werd in later tijd het woord stomboto ontleend, waarin het eerste element onvertaald bleef en betekenisloos. Het ligt voor de hand hier te veronderstellen, dat men het Nederlandse woord , stoom" niet kende en het daarom niet in verband bracht met het toch in een synonieme samenstelling bekende element smoko. Zekerheid is hier echter niet te geven.

Tenslotte delen wij hier dan het verzamelde materiaal mee: groep $I^{1}$ )

1 korkutreki (kurketrekker: kurk, een aftreksel maken)

2 freemusu (vleermuis: vliegen, muts)

3 pantioso (pandhuis: pand, huis)

4 pakoso (pakhuis: pak, huis)

5 sraktioso (slachthuis: slachten, huis)

6 trowoso (bruiloft: trouwen, huis)

7 brantiwin (brandewijn: brand, sterke drank)

8 brantimaka (doornstruik: brand, doorn)

9 fetikaka (vechtersbaas: vechten, haan)

10 smokosipi (stoomboot: rook, schip)

groep $I I$

1 tokofisi (stokvis: $f i s i=$ vis, tokotoko $=$ modder)

2 bunkopu (goedkoop: bun = goed)

3 brotsukru (broodsuiker, geraffineerde suiker: sukru = suiker)

4 stomboto (stoomboot: boto $=$ boot)

5 sjurkoro (zuurkool: koro $=\mathrm{kool}$ )

6 srudeki (zuurdeeg: deki $=$ deeg)

7 peprewoisi (peperhuis, puntzak: pepre = peper)

8 spikrikati (spiegelkat: spikri $=$ spiegel)

9 banabeki (bananenbek, vogelsoort: bana $=$ banaan) groep $I I I$

1 fingrutu (vingerhoed)

2 bedaki (biddag)

3 kempanki (kemphaan)

4 foroisi (voorhuis)

5 kumakoisi (gemakhuis, WC)

1) In deze groep zitten enkele woorden (zoals sraktioso), die slechts ver meld worden in verband met woorden als foroisi. 